\title{
Leacock Remains at McGill Some Notes on the Stephen Leacock Collection
}

\section{by Bruce Whiteman}

The Department of Rare Books and Special Collections, McGill University Libraries, houses one of Canada's major collections of Stephen Leacock books and manuscripts. This article describes the origins of the collection and the role of Leacock himself, and of his student, the Montreal book collector, Norman H. Friedman, in its foundation.

Le département des livres rares et collections spéciales des bibliothèques de l'Université McGill abrite l'une des plus importantes collections canadiennes d'ouvrages et de manuscrits de Stephen Leacock. Cet article décrit les origines de la collection et le rôle qu'ont joué Leacock lui-même et son étudiant, le collectionneur de livres montréalais Norman H. Friedman, dans sa fondation.

A Ithough we mark this year as the fiftieth anniversary of Stephen Leacock's death on March 28, 1944, it is also worth remarking that it was exactly a century ago, in 1894 , that Leacock published his earliest writing, twelve years before his first book. Fifty years of writing produced an enormous quantity of books and magazine pieces, and Leacock's fame meant that most of those books appeared in many editions and translations, both during and after his lifetime. The dedicated Leacock collector will not need an infinitely deep pocketbook, for the majority of the books is not particularly expensive; a great deal of shelf-space, however, is a sine qua non.

A single example may stand for many. Leacock's first collection of humour, Literary Lapses, was printed for the author by the Gazette Printing Co. and published on April 9, 1910 in an edition of 3,100 copies, after Houghton, Mifflin (who published his Elements of Political Science in June of 1906) had rejected it. The book sold "like hot pop corn" and "like hot cakes," as the author remarked later in inscribing two separate copies, ' and it has never been out of print. In addition to three copies of the first edition, the McGill collection includes copies of the first English edition (John Lane, 1911), an undated Musson edition (with an ownership inscription dated January 7, 1913), ${ }^{2}$ the "seventh edition" with the spine imprint of S.B. Gundy (1915), the first Penguin paperback edition (1939), the first New Canadian Library edition (1957) and a 1965 impression of the same, and the Collins White Circle paperback edition of 1945 (Canadian bibliographer R.E. Watters's copy).
Added to these must be appearances of individual stories in the book - "My Financial Career," for example, in the issue of Life for April 11, 1895, or as part of a group of miniature books published during the second World War by the Knights of Columbus - as well as translations into Romanian ("Cariera mea de Financiar") and Russian ("Moia finansovaia ker'era"). These items by no means represent completely the publishing history of Literary Lapses, but from them one can get some sense of the multiplicity of editions and forms that Leacock's work has taken over the last century.

The basis of the Leacock collection in the Department of Rare Books and Special Collections was formed by two important gifts. Leacock himself left a large aggregation of manuscripts ("literally barrels of manuscripts" as a Montreal newspaper described the gift at the time) ${ }^{3}$ in his will, and this gift arrived at the library in August of 1944. Included are partial or complete manuscripts for many of his books, among them Arcadian Adventures With the Idle Rich (1914). Leacock had also donated a few manuscripts shortly before his death, most importantly those of Charles Dickens, His Life and Work (1933) and Humour and Humanity (1937).

The second major donation was the private Leacock collection of Norman H. Friedman which he donated in 1945 and 1946. Friedman (1900-1981) was a student of Leacock's at McGill (his Bachelor of Commerce degree was conferred in 1921) and was one of the library's major donors. His gifts included collections 


\section{Leacock Remains at McGill}

of Rudyard Kipling, Robert Louis Stevenson, Christopher Morley, and the Boy Scout Movement, in addition to Leacock and a small collection of general books. A collection of the work of Arthur Szyk was also acquired from him by purchase. He was a successful businessman and manufacturer (candy and clothing), and collecting books was his passion. At the time of the gift, his Leacock collection was certainly the richest in private hands. After graduation he remained in touch with the writer, and indeed Leacock made a visit to his home in 1937 to look at the collection. On that visit he wrote the following in Friedman's guest book:

Looking over your wonderful and flattering collection of my works makes me almost want to hurry up to be dead, so that they can be aired out on exhibition at McGill and draw tears that will almost drown the statue on the campus that holds the tear jug. ${ }^{4}$

Staying in touch with Leacock allowed Friedman to get many of his books signed and inscribed, and indeed a number of them were gifts from Leacock himself.

Friedman kept a list of the collection with notes on the source and cost of each title, as well as the date when he received it. Most of his Leacock books were bought in Montreal, but he also acquired some American editions from the Gotham Book Mart in New York and scarcer items from Dora Hood in Toronto and Bertram Rota in London. ${ }^{5}$ His copy of Leacock's edition of Lahontan's Voyages, for example, was acquired (as a gift, according to a pencilled note in the copy) from the Dora Hood Book Room in 1939, seven years after publication. This book was long considered a great rarity, and the following note in Leacock's hand, written on p. [iv] of the Friedman copy, explains why:

I received, through Dr Burpee of Ottawa, a contract with the Graphic Co to do an introduction to Lahontan's journal with notes ... The company failed \& paid nothing ... But I found out long afterwards that some copies of the book had gone through the press though it was never on the market. I was never able to get a copy. ${ }^{6}$
Today the book is certainly scarce, but it is not as rare as Leacock thought; presumably at some point after the bankruptcy of Graphic Publishers in 1932, part of the edition was remaindered or otherwise came on the market.

In addition to books and manuscripts, the Friedman Leacock collection includes photographs and other graphic material, clippings and related ephemera (most interestingly a scrapbook about Leacock kept by Friedman in the 1930s and 1940s), some correspondence, and some personal papers, including the book list already cited. It is in all an extensive author collection and formed a broad base on which the McGill Leacock holdings have since ramified and expanded.

In the almost fifty years since Norman Friedman donated his Leacock collection to McGill, a number of important additions have been made both by gift and by purchase. In 1968, Dr. Orville W. Oughtred presented a group of nine letters, mainly to Leacock's mother and his brother Charles. In 1976, the private Leacock collection of John R. Witham was acquired at the Montreal Book Auctions (lot 27 in the sale of October 26). The collection included books, manuscripts, and a few letters, as well as an associated group of typescripts and proofs known as the British and International Press Ltd. Collection.

In 1984, with the help of a grant from the Social Sciences and Humanities Research Council of Canada, a group of manuscripts and letters was acquired from Mr. J. Robert Janes, whose father was Leacock's godson. The clou in the Janes collection is a notebook or diary of his publishing and speaking career that Leacock kept from January 7, 1901 ("First Lecture at McGill") to 1925. This notebook will be of immense importance to anyone brave enough to tackle Leacock's immense bibliography. A few representative entries from 1910 suggest its bibliographical richness:

April 1st Article. The Apology of a Professor [.] University Magazine. Saturday April. 9. Publication of "Literary Lapses", A Book of Sketches

May-June 1910. Series of V. Articles in Montreal Standard on Questions of 


\section{Leacock Remains at McGill}

the Day I. Socialism. II. Germany : [III] S. Africa [.] IV Imperial Unity [.] V. The Lords

June. Articles Hudson Bay : Canada \& the World's Wheat Supply : Canadian Women in the World of Art Publishers Press Syndicate.

Sunday. June. 19. 1910. Fragoletta. A Vaudeville Sketch

Friday June 24. Poem: Vanitas. A Song for Summer Time. Publishers Press.

The notebook also contains notes for two books, "Canada and the Future" and "Government and Industry," the latter a book which Leacock apparently was to write for the "LaSalle Extension University of Chicago." "7

In 1988 a group of Leacock papers was acquired in London at the Sotheby sale of July 21 and 22 (lot 204). This material had been put together by James Keddie, to whose magazine Answers Leacock made several contributions in the period from 1938 to 1942 . The lot included twenty-six letters as well as typescripts and proofs, and the final cost of $£ 2430$ was enormously pleasing given the fact that the material had been offered to McGill several years earlier (and declined) for $\$ 28,000.00$ (U.S.)! A small group of manuscripts and letters was purchased in 1987 from Mr. Gordon Glassco, and the most recent acquisition of any size was a batch of letters, manuscripts and ephemera donated to McGill in 1991 by Mrs. Barbara Whitely, who had received belp from Leacock in the 1930s when she was working on a series of radio broadcasts.

Among a number of smaller acquisitions which cannot be described here in detail, mention might be made of the following: two story manuscripts bought by Mr. F.A. Warren at the Sothby (Toronto) sale of October 29, 1969 (lots 86 and 87) and presented to McGill; a letter and a manuscript acquired at the Sotheby (Toronto) sale of November 8, 1988 (lot 254); two letters and a holograph notebook donated in 1989 by Mr. Alfred Pick; and individual Leacock letters bought from antiquarian booksellers Glenn Horowitz (1987 and 1988), Helen R. Kahn (1987), and Robert Shulman (1988).

In addition to the books and manuscripts which comprise most of the Leacock collection, the Print Collection in the Department of Rare Books and Special Collections contains several likenesses of Leacock, including paintings, drawings, and photographs. A print of one of the Karsh photographs of Leacock (taken in 1941) hangs in the Leacock Room (now the Department Head's office), as does the only moderately successful portrait done by Montreal artist Frederick Taylor in 1940.

Leacock continues to be one of the authors whom the Department of Rare Books and Special Collections collects in depth, and there remains a surprising amount of Leacock material in private hands that continues to come on to the market. The collection will never be complete, but that is the ideal towards which the Department works.

\section{Notes}

1. Copies 1 and 3 in the McGill collection have later inscriptions with notes by Leacock on the circumstances in which the book appeared.

2. This edition uses the Jobn Lane sheets with a cancel title-leaf. Musson (a Toronto publisher) seems often to have bought unsold stock, remainders, or foreign books in sheets, and issued them under its own imprint, frequently (and infuriatingly, as in this instance) without a date.

3. Montreal Star, February 16, 1945.

4. Quoted in the Montreal Gazette, April 6, 1970.

5. "Works of Dr. Stephen B. Leacock," an incomplete holograph list of the Norman Friedman Collection, Friedman Papers, McGill University Libraries, Department of Rare Books and Special Collections, MS 471.

6. Leacock evidently had forgotten that Dora Hood had provided him with a copy from her catalogue No. 15 (1935), as she relates in The Side Door: Twenty-Six Years in My Book Room (Toronto: Ryerson Press, 1958), pp. 77-9.

7. "Notebook," McGill University Libraries, Department of Rare Books and Special Collections, 
Leacock Papers, Ms. 668, VI, p. [68]. "Canada and the Future" is not the book which Leacock was to publish thirty-two years later as Canada: The Foundations of Its Future (Montreal: [s.n.], 1941).

8. The McGill Leacock Collection is one of three important Canadian institutional collections. The Stephen Leacock Museum in Orillia, Ontario, has extensive holdings of Leacock manuscripts and correspondance, as well as his personal library. The National Archives of Canada in Ottawa, Ontario, has Leacock papers mainly acquired from Barbara Nimmo, Leacock's niece. 